\title{
Nutritional errors in the first months of life and their association with asthma and atopy in preschool children
}

\author{
Simone Z. Strassburger, ${ }^{1}$ Márcia R. Vitolo, ${ }^{2}$ Gisele A. Bortolini, ${ }^{3}$ Paulo M. Pitrez, ${ }^{4}$ \\ Marcus H. Jones, ${ }^{4}$ Renato T. Stein ${ }^{4}$
}

\begin{abstract}
Objective: To evaluate the impact of exclusive breastfeeding and introduction of cow's milk in the first year of life on the diagnosis of asthma, wheezing, and atopy in children aged 3 to 4 years.

Methods: This is a cohort study nested in a randomized field trial investigating the effectiveness of dietary guidelines during the first year of life of children in the city of São Leopoldo, southern Brazil. Children who had their diet monitored during the first year of life, in a primary study, were revisited three years later, when their parents answered a questionnaire related to respiratory problems, applied during home visits by trained interviewers. Children were also skin-prick tested to assess responses to common environmental allergens.

Results: Of the 397 children followed during the first year of life, 354 were reassessed between 3 and 4 years of age. Prevalence of wheezing, evaluated for the 12 months prior to questionnaires, was $21.3 \%$, while prevalence of asthma and atopy was 5.5 and $28.7 \%$, respectively. Children fed cow's milk previous to being four months of life were significantly more likely to have asthma between three and four years of age (OR 3.22; $95 \%$ CI 1.05-9.80). In the same line, exclusive breastfeeding for a period shorter than six months was marginally associated with atopy.

Conclusions: The early introduction of cow's milk was an important risk factor for triggering asthma/wheeze symptoms at the age of 4 years. Exclusive breastfeeding for longer than six months was also potentially associated with protection against the development of atopy. The results of this study suggest that dietary interventions during the first year of life have the potential to reduce the impact of asthma, and possibly, atopy.
\end{abstract}

J Pediatr (Rio J). 2010;86(5):391-399: Breastfeeding, cow's milk, asthma, diet, child.

\section{Introduction}

Asthma is the most common chronic disease in the first decade of life, being responsible for the high frequency of respiratory symptoms at this age. Several studies using the methodological basis of the International Study of Asthma and Allergies in Childhood (ISAAC) have shown the high prevalence of asthma and allergic diseases in children and have served as a standard for epidemiological studies in various communities worldwide. ${ }^{1-3}$ Despite not being designed to study the prevalence of respiratory symptoms and diseases in preschool children, the ISAAC questionnaire

1. Mestre. Programa de Pós-Graduação em Medicina/Pediatria e Saúde da Criança, Pontifícia Universidade Católica do Rio Grande do Sul (PUCRS), Porto Alegre, RS, Brazil.

2. Doutora. Professora adjunta, Departamento de Saúde Coletiva, Universidade Federal de Ciências da Saúde de Porto Alegre (UFCSPA), Porto Alegre, RS, Brazil.

3. Mestre. Programa de Pós-Graduação em Ciências Médicas, UFCSPA, Porto Alegre, RS, Brazil.

4. Doutor. Professor adjunto, Departamento de Pediatria, Faculdade de Medicina (FAMED), PUCRS, Porto Alegre, RS, Brazil.

No conflicts of interest declared concerning the publication of this article.

Suggested citation: Strassburger SZ, Vitolo MR, Bortolini GA, Pitrez PM, Jones MH, Stein RT. Nutritional errors in the first months of life and their association with asthma and atopy in preschool children. J Pediatr (Rio J). 2010;86(5):391-399.

Manuscript submitted Dec 07 2009, accepted for publication Aug 022010.

doi:10.2223/JPED.2031 
has been widely used in the evaluation of preschool children. ${ }^{4}$ In Brazil, studies have also shown a large impact of asthma in urban populations. ${ }^{5} \mathrm{~A}$ number of risk factors have been related to this high incidence of asthma or asthma symptoms in affected populations. Over the past two decades, there has been increasing interest in elucidating the pathophysiology of the disease, as well as its main risk factors. Recently, the role of diet, particularly feeding practices during the first year of life, has been implicated in the development of asthma. Some of these studies reported that exclusive breastfeeding for four months reduced the risk of asthma at the ages of four and six years. ${ }^{6-8}$

Halken ${ }^{9}$ reviewed publications that investigated the association of feeding practices with asthma and allergies. A series of studies in this review suggest that longer duration of exclusive breastfeeding and/or later introduction of complementary foods have been associated with outcome variables such as: lower frequency of cow's milk protein allergy, atopic dermatitis, wheezing, and asthma in later childhood, especially among children with a family history of atopy. This topic remains somewhat controversial, with studies suggesting that breastfed children with asthmatic mothers might have increased risk of asthma later in life, including reduced pulmonary expiratory flows. ${ }^{10,11}$ The early introduction of cow's milk has been associated with allergic diseases, fecal blood loss, and iron deficiency. ${ }^{12-14}$

The studies published to date, discussing the impact of diet on respiratory diseases, are based mainly on recall/retrospective data. In the present study, information obtained from a detailed prospective monitoring of diet during the first year of life, in low-income children from the metropolitan area of Porto Alegre, southern Brazil, was used to assess respiratory outcomes and markers of allergy among children aged 3-4 years. ${ }^{15}$

\section{Methods}

\section{Study population and design}

This is a cohort study nested in a randomized field trial investigating the effectiveness of dietary guidelines during the first year of life, recommended by the Brazilian Ministry of Health (2002), in the city of São Leopoldo, southern Brazil. These guidelines emphasize the importance of exclusive breastfeeding until 6 months of age. The methods and data referring to the nutrition education program are detailed in a previous publication by Vitolo et al. ${ }^{15}$ According to that study protocol, one group received guidance on the benefits of exclusive breastfeeding, and such information was not made available in a formal way to the control group. Children who participated in the study were recruited at birth at Hospital Centenário, located in the city of São Leopoldo, in the metropolitan area of Porto Alegre, Brazil. Health care to these children was provided by the Brazilian public Unified Health System (SUS).
In the first phase of the study, between October 2001 and June 2002, nutrition school students identified all eligible newborns for the study at the city's hospital nursery, i.e., birth weight greater than 2,500 g and gestational age greater than 37 weeks. The exclusion criteria were: HIVpositive mothers, congenital malformations, newborns admitted to the intensive care unit, and multiple births. Mothers of newborns who met the inclusion criteria were informed about the study and invited to participate. Of all newborns eligible for the study, $90 \%$ of mothers agreed to participate.

\section{General and nutritional variables}

Previously trained undergraduate students collected the variables used in this study during home visits at the ages of six, and twelve months, and again between three and four years of age. At six months, variables that could help in the composition of the profile of the study population were recorded, such as: maternal education, monthly family income, exclusive breastfeeding (defined as the use of breastfeeding as the only food offered to the child, with no offer of tea and water or any other item), and child's age at introduction of fresh fruit or fruit juice, salty pureed foods, and cow's milk. At twelve months, foods introduced in the period from six to twelve months were reviewed and exposure to maternal smoking, or from other family member, was analyzed during the first year of life. The variables included in the current study were: duration of breastfeeding (with dichotomous variables at 4 or 6 months of age), introduction of cow's milk, introduction of fruit or fruit juice and salty pureed foods (all these with a cutoff point at 4 months of age).

\section{Evaluation of wheezing and asthma}

A questionnaire to assess respiratory symptoms and asthma was administered between three and four years of age. For investigation of respiratory problems, we used a questionnaire validated for Brazilian children aged seven to nine years, based on material used by the ISAAC. In this questionnaire, parents answered specific questions regarding respiratory diseases. Wheezing was defined by the question: "Has your child had wheezing (a rasp or whistling sound) in the past 12 months?" Asthma was defined as a positive combination of the previous question with the following question: "Has your child ever had asthma?" Information related to the environment where children live, their medical history and family history of diseases and demographic data were collected during home visits by trained interviewers.

\section{Evaluation of atopy}

For outpatient assessment of atopy, children were skinprick tested to common environmental allergens (cat dander, 
pollen, mixed trees, and house dust mite-Dermatophagoides pteronissinus, Dermatophagoides farinae). A technician whose performance had been previously validated carried out the tests. Lancets, extracts and control solutions were provided by ALK-Abello laboratory (Spain). As for the influence of circadian cycle on skin response to allergens and histamine, all tests were performed in the morning. The reactions were recorded as the sum of the largest wheal diameter plus the diameter perpendicular to it, divided by two, minus the value of the negative control; wheal sizes of $3 \mathrm{~mm}$ or greater were considered positive. Patients were defined as atopic if they were positive for at least one of the allergens tested.

\section{Statistical analyses}

Statistical analysis was performed using the Statistical Package for the Social Sciences (SPSS) version 13.0. Since this study is derived from a randomized field trial on the effectiveness of a nutrition program in other outcomes, the prevalence of wheezing, asthma and atopy was compared between the groups that participated in the initial study ${ }^{15}$ to assume the hypothesis that the intervention did not alter the prevalence of the outcomes evaluated. There were no differences in prevalence between the intervention (I) and control (C) groups for: wheezing, I:26.0\%, C:17.9\% ( $\mathrm{p}=$ $0.068)$; asthma, I:7.5\%, $C: 4.0 \%(p=0.151)$; and atopy, $I: 32.8 \%, C: 25.7 \%(p=0.155)$. Once there was confidence no bias was introduced by this procedure, analyses were performed regardless of which group the child belonged, thus increasing statistical power for this sample.

Univariate analysis was used to obtain the frequency of all variables of interest and to examine their distribution. Bivariate analysis was performed for each variable regardless of the relationship with outcome variables (wheezing in the past 12 months, asthma, and atopy) using Pearson's chisquare test. For each outcome a three-level hierarchical logistic regression model was adjusted, selecting the variables with $p<0.2$ on crude analysis. The variables sociodemographic status and sex were allocated within the first level (Level I). Within the second level (Level II), the model included Level I variables with $\mathrm{p}<0.05$, in addition to maternal and paternal variables. The third level (Level III) included variables related to feeding practices in the first year of life, with $p<0.2$ on crude analysis, and variables that remained in previous models, being considered statistically significant when $\mathrm{p}<0.05$. The modeling performed allowed us to identify, among the variables studied, the main predictors of the outcomes of interest.

The variables breastfeeding, exclusive breastfeeding, introduction of fruit and/or fruit juice, introduction of cow's milk, and introduction of salty pureed foods were analyzed using different cutoff points. Thus, the dichotomous variables that were most strongly associated with the outcomes remained in the model.

\section{Ethical aspects}

The research project was approved by the Research Ethics Committee of Pontifícia Universidade Católica do Rio Grande do Sul (PUCRS), Brazil. The questionnaire was administered and skin-prick tests were performed after the mothers signed a written consent form. Mothers were informed of the cases testing positive for atopy.

\section{Results}

Of the 397 children followed during the first year of life (first phase of the study), a total of 354 was assessed in the second phase of the study $(89.2 \%)$, from January to June 2006 , during home visits by trained interviewers who collected data on respiratory problems. The reasons for losses in the first phase were: child's death (1), refusal to continue participating in the study (5), address not found (12), change of address/moving to other cities (18), change of address/not informed (7). In the second phase of the project, during home visits, 347/354 mothers or legal guardians answered adequately the questionnaire on respiratory problems ( 7 subjects had incomplete questionnaires and information was not enough; these were also considered losses to follow-up). Subsequently, 328 children (94.5\%) attended a teaching hospital outpatient clinic for skin-prick testing.

Of all children participating in the study, 196 were male $(56.4 \%)$. Total family income, expressed as National minimum wage, revealed that two thirds (238/340) of families lived with an income of less than three minimum wages. Formal maternal education was lower than 8 years for $56.0 \%$ of the total sample (196/347). The children's mean age was $47.74 \pm 2.68$ months at the time of evaluation of respiratory outcomes.

In the last 12 months prior to the home visit, prevalence of wheezing was $21.3 \%$; asthma, $5.5 \%$; and atopy, $28.7 \%$. Table 1 describes these data, in addition to family history of respiratory diseases, exposure to cigarette smoking during the first year of life, and data on the child's diet in the first year. The frequency of children's exposure to environmental tobacco smoke from any person within their homes during the first year of life was $41.0 \%$ for the children evaluated. Only one third of children were exclusively breastfed beyond 4 months of age, and cow's milk had already been introduced to $40 \%$ of children before 4 months of age (Table 1 ).

Table 2 describes the prevalence of wheezing in the past 12 months in each group of independent variables. The crude odds ratio showed that children of parents with a history of allergic rhinitis and asthma were more likely to present wheezing. Early introduction of cow's milk and fruit juice or exclusive breastfeeding up to 4 or 6 months of age were not associated with wheezing at the age of 4 years. After multiple logistic regression, only maternal history of rhinitis remained associated with presence of wheezing. 
Table 1 - Frequency of clinical variables, diet in the first year of life, and family history of respiratory diseases based on 347 children with a questionnaire completed between 3 and 4 years of age (except for skin-prick tests, $n=328$ )

\begin{tabular}{lcc}
\hline Variables* & $\mathbf{n}$ & \% \\
\hline Wheezing in the past 12 months & 74 & 21.3 \\
Asthma & 19 & 5.5 \\
Atopy ( $\geq 1$ positive allergen) & 94 & 28.7 \\
Maternal history of asthma & 44 & 12.8 \\
Paternal history of asthma & 26 & 8.0 \\
Exclusive breastfeeding $\geq 4$ months & 124 & 36.0 \\
Exclusive breastfeeding $\geq 6$ months & 41 & 11.9 \\
Introduction of cow's milk $\leq 4$ months & 119 & 40.3 \\
Exposure to tobacco smoke in the first year of life & & \\
Father & 38 & 9.6 \\
Mother & 61 & 15.4 \\
Both & 35 & 8.9 \\
\hline
\end{tabular}

* Not all variables have the same denominator due to lack of information on some variables.

The results of crude and adjusted analyses of risk factors for asthma are shown in Table 3. Children fed cow's milk before 4 months of life were significantly more likely to have asthma. The risk of children having asthma at the age of 4 years, in the crude bivariate analysis, was three times greater for children of mothers with a history of rhinitis and four times greater for children of mothers with a history of asthma. After hierarchical adjusted regression, children fed cow's milk before 4 months of life were three times more likely to have asthma at the age of 4 years (OR: 3.22 ; 95\%CI 1.05-9.80).

Table 4 presents the results of the analysis of risk factors for atopy. Children of parents with a history of rhinitis who were breastfed for less than 6 months or who were fed fruit or fruit juices before 4 months of age were more likely to have atopy according to the crude bivariate analysis. After the adjusted analysis, children who were exclusively breastfed for 6 months or less showed a marginally higher risk of having at least one positive skin test between 3 and 4 years of age. Paternal history of rhinitis also remained significantly associated with atopy.

\section{Discussion}

Several risk factors have been highlighted in an attempt to justify the different levels of prevalence of asthma and allergic diseases in comparisons within and between countries. Environmental factors such as allergen sensitization in early childhood, as well as viral, bacterial and parasitic infections appear to have strong influence on the physiopathogenesis of asthma and atopy. ${ }^{16-19}$ One factor that is increasing the attention of researchers in the area as a possible risk variable for asthma and allergic diseases is related to dietary influence on these first years of life. This interest in studying the importance of diet has so far resulted in very few prospective studies, and this is perhaps one of the greatest strengths of our results.

Our most significant finding was that children fed cow's milk before four months of life, thus breaking the cycle of exclusive breastfeeding, were three times more likely to have asthma at the age of four years, regardless of other known risk factors associated with asthma. In Brazil, there is evidence that during the first two years of life children are fed mainly milk products, including flour and sugar added to milk formulas or processed cow's milk, and that introduction of these foods often occurs before six months of life. ${ }^{20,21} \mathrm{~A}$ possible consequence of this early introduction of cow's milk would be the increased incidence of cow's milk allergy observed in several countries, with prevalence rates ranging from 1.9 to $7.5 \% .22$ Sampson reports the increased prevalence of allergic diseases as manifestations associated with cow's milk allergy. ${ }^{23,24}$ Very recent studies suggest that the presence of an intestinal microbial flora rich in bacteria or the use of probiotics may inhibit symptoms of respiratory diseases in children ${ }^{25}$ through the activation of innate immune response mechanisms. ${ }^{26}$ The impact of 
reducing the duration of exclusive breastfeeding observed in our study and in several other studies may suggest that diet-related mechanisms can interfere with the development of respiratory diseases in children.

One of the most important recent ISAAC findings concerns the definition that asthma in highly developed populations is more strongly associated with atopy, whereas this relationship is much weaker in low-income populations. ${ }^{27}$ An important finding is that asthma prevalence is high, especially in low-income Brazilian populations, but nonatopic asthma appears to be the most common phenotype. ${ }^{28}$ One of the current hypotheses explaining this phenomenon is that a less hygienic environment, and therefore more "aggressive," despite being protective against atopy, can

Table 2 - Crude and adjusted analysis (hierarchical logistic model) of risk factors for wheezing in the past 12 months in children aged 3 to 4 years

\begin{tabular}{|c|c|c|c|c|c|}
\hline \multirow[b]{2}{*}{ Level/variables* } & \multirow[b]{2}{*}{$\mathrm{n} / \mathrm{N}$ total $(\%)$} & \multicolumn{2}{|c|}{ Crude analysis } & \multicolumn{2}{|c|}{ Adjusted analysis } \\
\hline & & OR $(95 \% \mathrm{CI})$ & $\mathbf{p}$ & OR $(95 \% \mathrm{CI})$ & $\mathbf{p}$ \\
\hline \multicolumn{6}{|l|}{ Level I } \\
\hline \multicolumn{6}{|l|}{ Sex } \\
\hline Male & $44 / 196(22.4)$ & $1.16(0.69-1.96)$ & 0.561 & - & \\
\hline Female & $30 / 151(19.9)$ & 1 & - & & \\
\hline \multicolumn{6}{|l|}{ Family income } \\
\hline$<3$ minimum wages & $50 / 237(21.1)$ & $0.90(0.52-1.58)$ & 0.732 & - & \\
\hline$\geq 3$ minimum wages & $23 / 101(22.8)$ & 1 & & & \\
\hline \multicolumn{6}{|c|}{ Maternal level of education } \\
\hline$<8$ years & $40 / 195(20.5)$ & $0.88(0.53-1.48)$ & 0.652 & - & \\
\hline$\geq 8$ years & $34 / 151(22.5)$ & 1 & & & \\
\hline \multicolumn{6}{|c|}{ Level II } \\
\hline \multicolumn{6}{|c|}{ Maternal history of asthma } \\
\hline Positive & $17 / 44(38.6)$ & $2.69(1.37-5.27)$ & 0.003 & $2.08(0.96-4.50)$ & 0.061 \\
\hline Negative & $57 / 301(18.9)$ & 1 & & 1 & \\
\hline \multicolumn{6}{|c|}{ Maternal history of rhinitis } \\
\hline Positive & $34 / 110(30.9)$ & $2.17(1.27-3.68)$ & 0.004 & $2.17(1.26-3.72)$ & 0.005 \\
\hline Negative & $40 / 234(17.1)$ & 1 & & 1 & \\
\hline \multicolumn{6}{|c|}{$\begin{array}{l}\text { Maternal and/or paternal smoking } \\
\text { in the first year of life }\end{array}$} \\
\hline Yes & $28 / 60(24.6)$ & $1.30(0.76-2.23)$ & 0.323 & - & \\
\hline No & $46 / 281(19.9)$ & 1 & & & \\
\hline \multicolumn{6}{|c|}{ Paternal history of asthma } \\
\hline Positive & $9 / 26(34.6)$ & $2.16(0.91-5.09)$ & 0.072 & $1.40(0.52-3.72)$ & 0.498 \\
\hline Negative & $59 / 300(19.7)$ & 1 & 1 & & \\
\hline \multicolumn{6}{|c|}{ Paternal history of rhinitis } \\
\hline Positive & $19 / 60(31.7)$ & $2.15(1.15-4.04)$ & 0.015 & $1.85(0.91-3.76)$ & 0.088 \\
\hline Negative & $47 / 266(17.7)$ & 1 & & 1 & \\
\hline \multicolumn{6}{|l|}{ Level III } \\
\hline \multicolumn{6}{|l|}{ Exclusive breastfeeding } \\
\hline$<4$ months & $53 / 220(24.1)$ & $1.52(0.87-2.67)$ & 0.139 & $1.33(0.73-2.41)$ & 0.341 \\
\hline$\geq 4$ months & $21 / 122(17.2)$ & 1 & & 1 & \\
\hline \multicolumn{6}{|c|}{ Introduction of cow's milk } \\
\hline$<4$ months & $28 / 119(23.5)$ & $1.26(0.72-2.23)$ & 0.414 & - & \\
\hline$\geq 4$ months & $34(19.5)$ & 1 & & & \\
\hline \multicolumn{6}{|c|}{ Introduction of fruit and/or fruit juice } \\
\hline$<4$ months & $14 / 174(26.4)$ & $1.34(0.68-2.64)$ & 0.368 & - & \\
\hline$\geq 4$ months & $60 / 285(21.1)$ & 1 & & & \\
\hline \multicolumn{6}{|c|}{ Introduction of salty pureed foods } \\
\hline$<4$ months & $10 / 32(31.3)$ & $1.73(0.78-3.86)$ & 0.171 & $1.68(0.72-3.93)$ & 0.229 \\
\hline$\geq 4$ months & $62 / 299(20.7)$ & 1 & & 1 & \\
\hline
\end{tabular}


strongly induce asthma and wheezing in childhood. A recent study from our group ${ }^{29}$ showed that bronchiolitis early in life is the strongest risk factor for asthma at the age of 11 years, whereas atopy seems to be a minor risk factor for the determination of the disease.
The main finding of our study is that the early introduction of cow's milk, interrupting exclusive breastfeeding, may play a significant role in the explanation of asthma/ recurrent wheeze among low-income populations, such as this in Brazil, particularly when one can demonstrate

Table 3 - $\quad$ Crude and adjusted analysis (hierarchical logistic model) of risk factors for asthma in children aged 3 to 4 years

\begin{tabular}{|c|c|c|c|c|c|}
\hline \multirow[b]{2}{*}{ Level/variables* } & \multirow[b]{2}{*}{$\mathrm{n} / \mathbf{N}$ total $(\%)$} & \multicolumn{2}{|c|}{ Crude analysis } & \multicolumn{2}{|c|}{ Adjusted analysis } \\
\hline & & OR $(95 \% C I)$ & $\mathbf{p}$ & OR $(95 \% \mathrm{CI})$ & $\mathbf{p}$ \\
\hline \multicolumn{6}{|l|}{ Level I } \\
\hline \multicolumn{6}{|l|}{ Sex } \\
\hline Male & $11 / 196(5.6)$ & $1.06(0.41-2.71)$ & 0.899 & - & \\
\hline Female & $8 / 151(5.3)$ & 1 & & & \\
\hline \multicolumn{6}{|l|}{ Family income } \\
\hline$<3$ minimum wages & $14237(5.9)$ & $1.20(0.42-3.44)$ & 0.727 & - & \\
\hline$\geq 3$ minimum wages & $5 / 101(5.0)$ & 1 & & & \\
\hline \multicolumn{6}{|c|}{ Maternal level of education } \\
\hline$<8$ years & $9 / 195(4.6)$ & $0.68(0.27-1.72)$ & 0.416 & - & \\
\hline$\geq 8$ years & $10 / 151(6.6)$ & 1 & & & \\
\hline \multicolumn{6}{|l|}{ Level II } \\
\hline \multicolumn{6}{|c|}{ Maternal history of asthma } \\
\hline Positive & $7 / 44(15.9)$ & $4.55(1.68-12.29)$ & 0.001 & $2.60(0.78-8.61)$ & 0.117 \\
\hline Negative & $12 / 301(4.0)$ & 1 & & 1 & \\
\hline \multicolumn{6}{|c|}{ Maternal history of rhinitis } \\
\hline Positive & $12 / 110(10.9)$ & $3.97(1.51-10.38)$ & 0.003 & $2.17(0.71-6.65)$ & 0.172 \\
\hline Negative & $7 / 234(3.0)$ & 1 & & 1 & \\
\hline \multicolumn{6}{|c|}{$\begin{array}{l}\text { Maternal and/or paternal smoking } \\
\text { in the first year of life }\end{array}$} \\
\hline Yes & $9 / 114(7.9)$ & $1.89(0.74-4.80)$ & 0.172 & - & \\
\hline No & $10 / 231(4.3)$ & 1 & & & \\
\hline \multicolumn{6}{|c|}{ Paternal history of asthma } \\
\hline Positive & $2 / 26(7.7)$ & $1.47(0.32-6.8) 0.613$ & & - & \\
\hline Negative & $16 / 300(5.3)$ & 1 & & & \\
\hline \multicolumn{6}{|c|}{ Paternal history of rhinitis } \\
\hline Positive & $6 / 60(10.0)$ & $2.35(0.84-6.54)$ & 0.093 & $1.99(0.67-5.90)$ & 0.211 \\
\hline Negative & $12 / 266(4.5)$ & 1 & & 1 & \\
\hline \multicolumn{6}{|l|}{ Level III } \\
\hline \multicolumn{6}{|l|}{ Breastfeeding } \\
\hline$<6$ months & $9 / 128(7.0)$ & $1.55(0.61-3.92)$ & 0.351 & - & \\
\hline$\geq 6$ months & $10 / 215(4.7)$ & 1 & & & \\
\hline \multicolumn{6}{|c|}{ Introduction of cow's milk } \\
\hline$<4$ months & $12 / 119(10.1)$ & $3.79(1.29-11.06)$ & 0.010 & $3.22(1.05-9.80)$ & 0.039 \\
\hline$\geq 4$ months & $15 / 174(2.9)$ & 1 & & 1 & \\
\hline \multicolumn{6}{|c|}{ Introduction of fruit and/or fruit juice } \\
\hline$<4$ months & 4/53 (7.5) & $1.46(0.46-4.61)$ & 0.507 & - & \\
\hline$\geq 4$ months & $15 / 285(5.3)$ & 1 & & & \\
\hline \multicolumn{6}{|c|}{ Introduction of salty pureed foods } \\
\hline$<4$ months & $4 / 32(12.5)$ & $2.70(0.84-8.70)$ & 0.084 & $2.24(0.62-8.10)$ & 0.216 \\
\hline$\geq 4$ months & $15 / 299(5.0)$ & 1 & & & \\
\hline
\end{tabular}


that, in this population, almost $70 \%$ of children were not exclusively breastfed after four months of age. Therefore, our findings add important and novel information to a model that attempts to explain the risk factors associated with nonatopic asthma in Brazil.
Wheezing was not shown to be associated with the markers of diet studied herein. One hypothesis for these results is that wheezing at this age group is more closely associated with a phenotype of transient disease of childhood, other than asthma, and closely identified with wheezing

Table 4 - Crude and adjusted analysis (hierarchical logistic model) of risk factors for atopy in children aged 3 to 4 years

\begin{tabular}{|c|c|c|c|c|c|}
\hline \multirow[b]{2}{*}{ Level/variables* } & \multirow[b]{2}{*}{$\mathrm{n} / \mathrm{N}$ total $(\%)$} & \multicolumn{2}{|c|}{ Crude analysis } & \multicolumn{2}{|c|}{ Adjusted analysis } \\
\hline & & OR (95\%CI) & $\mathbf{p}$ & OR $(95 \% \mathrm{CI})$ & $\mathbf{p}$ \\
\hline \multicolumn{6}{|l|}{ Level I } \\
\hline \multicolumn{6}{|l|}{ Sex } \\
\hline Male & $58 / 187(31.0)$ & $1.31(0.80-2.13)$ & 0.277 & - & \\
\hline Female & $36 / 141(25.5)$ & 1 & & & \\
\hline \multicolumn{6}{|l|}{ Family income } \\
\hline$<3$ minimum wages & $57 / 222(25.7)$ & $0.65(0.38-1.08)$ & 0.099 & $0.67(0.38-1.16)$ & 0.154 \\
\hline$\geq 3$ minimum wages & $34 / 98(34.7)$ & 1 & & 1 & \\
\hline \multicolumn{6}{|c|}{ Maternal level of education } \\
\hline$<8$ years & $51 / 182(28.0)$ & $0.92(0.57-1.49)$ & 0.746 & - & \\
\hline$\geq 8$ years & $43 / 142(29.7)$ & 1 & & & \\
\hline \multicolumn{6}{|l|}{ Level II } \\
\hline \multicolumn{6}{|c|}{ Maternal history of asthma } \\
\hline Positive & $16 / 42(38.1)$ & $1.62(0.82-3.19)$ & 0.156 & $1.64(0.78-3.43)$ & 0.184 \\
\hline Negative & $78 / 284(27.5)$ & 1 & & 1 & \\
\hline \multicolumn{6}{|c|}{ Maternal history of rhinitis } \\
\hline Positive & $34 / 104(32.7)$ & $1.30(0.78-2.16)$ & 0.304 & - & \\
\hline Negative & $60 / 221(27.1)$ & 1 & & & \\
\hline \multicolumn{6}{|c|}{$\begin{array}{l}\text { Maternal and/or paternal smoking } \\
\text { in the first year of life }\end{array}$} \\
\hline Yes & $33 / 105(31.4)$ & $1.21(0.72-2.00)$ & 0.461 & - & \\
\hline No & $61 / 222(27.5)$ & 1 & & & \\
\hline \multicolumn{6}{|c|}{ Paternal history of asthma } \\
\hline Positive & $8 / 26(30.8)$ & $1.15(0.48-2.76)$ & 0.744 & - & \\
\hline Negative & $78 / 281(27.8)$ & 1 & & & \\
\hline \multicolumn{6}{|c|}{ Paternal history of rhinitis } \\
\hline Positive & $23 / 59(39.0)$ & $1.95(1.07-3.56)$ & 0.026 & $1.90(1.03-3.51)$ & 0.040 \\
\hline Negative & $61 / 248(24.6)$ & 1 & & 1 & \\
\hline \multicolumn{6}{|l|}{ Level III } \\
\hline \multicolumn{6}{|l|}{ Breastfeeding } \\
\hline$<6$ months & $44 / 122(36.1)$ & $1.72(1.05-2.81)$ & 0.028 & $1.61(0.94-2.75)$ & 0.077 \\
\hline$\geq 6$ months & $50 / 203(24.6)$ & 1 & & 1 & \\
\hline \multicolumn{6}{|c|}{ Introduction of cow's milk } \\
\hline$<4$ months & $36 / 111(32.4)$ & $1.23(0.73-2.08)$ & 0.425 & - & \\
\hline$\geq 4$ months & $47 / 168(28.0)$ & 1 & & & \\
\hline \multicolumn{6}{|c|}{ Introduction of fruit and/or fruit juice } \\
\hline$<4$ months & $21 / 52(40.4)$ & $1.85(1.00-3.43)$ & 0.048 & $1.39(0.70-2.74)$ & 0.335 \\
\hline$\geq 4$ months & $72 / 269(26.8)$ & 1 & & 1 & \\
\hline \multicolumn{6}{|c|}{ Introduction of salty pureed foods } \\
\hline$<4$ months & $8 / 31(25.8)$ & $0.83(0.36-1.95)$ & 0.682 & - & \\
\hline$\geq 4$ months & $83 / 283(29.3)$ & 1 & & & \\
\hline
\end{tabular}

$95 \% \mathrm{Cl}=95 \%$ confidence interval; OR = odds ratio.

* Not all subjects have complete information for all variables. 
associated with viral infection. ${ }^{30}$ Since this study was not designed to investigate diet outcomes in different phenotypes of childhood wheezing, the lack of an association might indicate that the study was underpowered to investigate these relationships.

Another important finding of the current study is that interruption of breastfeeding before six months of age is potentially associated with an increased risk of atopy. In the unadjusted analysis, this risk is $70 \%$ higher in children who were exclusively breastfed for less than six months; however, this analysis loses statistical significance when adjusted for other risk factors. A possible explanation is that a type 2 error has occurred and, in a larger sample, this analysis would have proven to be significant. Evidence in the literature suggests an association of early introduction of cow's milk with a number of morbidities in children, such as: higher frequency of infectious diseases, malnutrition, diarrhea, and specific deficiencies of micronutrients such as zinc, iron and vitamin $A,{ }^{31}$ all substances present in breast milk, in addition to antibodies that protect children against common childhood infections.

Studies such as those conducted by Chulada et al. ${ }^{32}$ and van Odjik et al. ${ }^{33}$ state that the longer the duration of breastfeeding, the lower the risk of developing allergic diseases. A comprehensive review on the subject, conducted in 2005 by Friedman \& Zeiger, 34 also concludes that breastfeeding can protect against allergic diseases. Nevertheless, there are authors who suggest that the increased risk for asthma and eczema is associated with breastfeeding, particularly in mothers who have asthma and eczema. ${ }^{10,11}$ In contrast to those findings, some researchers indicate that the protective effect of breastfeeding on respiratory and allergic diseases is higher in children with a positive family history of atopy, suggesting that diet and other risk factors for asthma and atopy should be investigated in populations of atopic and nonatopic asthmatics. The present study, however, was not designed or able to test populations of atopic and nonatopic asthmatics independently.

One consideration that must be addressed with respect to the interpretation of some results of this study concerns the difficulty in confirming a diagnosis of asthma in children younger than 5 years and, therefore, for this age group, some authors use the term persistent wheezing. Another limitation of this study lies in the fact that the ISAAC questionnaire employed here has not been validated for use in children at this age group. Nevertheless, this generalization including other patient groups has been made, even recently, 35,36 by different authors, and we believe that this decision does not significantly compromise the importance of the reported results.

In summary, our study indicates that common nutritional errors observed especially in the low-income Brazilian population may be associated with diseases of high prevalence in the country, such as asthma. Even more significant is the fact that simple strategies for nutrition education, as those suggested by the World Health Organization (WHO) and the Brazilian Ministry of Health, set in practice here and tested by Vitolo et al., ${ }^{37}$ are feasible and potentially likely to positively change dietary practices of the population. Considering that few preventive measures appear to have significant impact on the treatment of childhood asthma, it is encouraging to verify that results as those of our study indicate that the delayed introduction of cow's milk beyond the first four months of life is associated with the protection for asthma/recurrent wheeze between 3 and 4 years of age, and that exclusive breastfeeding for a period beyond the first six months has the potential to protect against the development of atopy in children. Further studies should be conducted to confirm our findings, mainly to verify whether these markers of diet are more closely associated with different asthma phenotypes and whether they can be applied to different social strata of the Brazilian population.

\section{References}

1. Worldwide variation in prevalence of symptoms of asthma, allergic rhinoconjunctivitis and atopic eczema: ISAAC. The International Study of Asthma and Allergies in Childhood (ISAAC) Steering Committee. Lancet. 1998;351:1225-32.

2. Pearce N, Aït-Khaled N, Beasley R, Mallol J, Keil U, Mitchel E, et al. Worldwide trends in the prevalence of asthma symptoms: phase III of the International Study of Asthma and Allergies in Childhood (ISAAC). Thorax. 2007;62:758-66.

3. Lai CK, Beasley R, Crane J, Foliaki S, Shah J, Weiland S; International Study of Asthma and Allergies in Childhood Phase Three Study Group. Global variation in the prevalence and severity of asthma symptoms: phase three of the International Study of Asthma and Allergies in Childhood (ISAAC). Thorax. 2009;64:476-83.

4. Tai A, Volkmer R, Burton A. Prevalence of asthma symptoms and atopic disorders in preschool children and the trend over a decade. J Asthma. 2009;46:343-6.

5. Solé D, Wandalsen GF, Camelo-Nunes IC, Naspitz CK; ISAAC Brazilian Group. Prevalence of symptoms of asthma, rhinitis, and atopic eczema among Brazilian children and adolescents identified by the International Study of Asthma and Allergies in Childhood (ISAAC) - Phase 3. J Pediatr (Rio J). 2006;82:341-6.

6. Schneider AP, Stein RT, Fritscher CC. The role of breastfeeding, diet and nutritional status in the development of asthma and atopy. J Bras Pneumol. 2007;33:454-62.

7. Kull I, Almqvist C, Lilja G, Pershagen G, Wickman M. Breastfeeding reduces the risk of asthma during the 4 years of life. J Allergy Clin Immunol. 2004;114:755-60.

8. Oddy $\mathbf{W H}$, Peat JK, de Klerk NH. Maternal asthma, infant feeding, and the risk of asthma in childhood. J Allergy Clin Immunol. 2002;110:65-7.

9. Halken S. What causes allergy and asthma? The role of dietary factors. Pediatr Pulmonol Suppl. 2004;26:223-4.

10. Guilbert TW, Stern DA, Morgan WJ, Martinez FD, Wright AL. Effect of breastfeeding on lung function in childhood and modulation by maternal asthma and atopy. Am J Respir Crit Care Med. 2007; 176:843-8. 
11. Sears MR, Greene JM, Willan AR, Taylor DR, Flannery EM, Cowan JO, et al. Long-term relation between breastfeeding and development of atopy and asthma in children and young adults: a longitudinal study. Lancet. 2002;360:901-7.

12. Sociedade Brasileira de Pediatria. Reflexões sobre o consumo de leite de vaca integral pelo lactente: consenso do Departamento Científico de Gastroenterologia da Sociedade Brasileira de Pediatria. Rio de Janeiro; 2003.

13. Host A, Jacobsen MP, Halken S, Holmenlund D. The natural history of cow's milk protein allergy/intolerance. Eur J Clin Nutr. 1995;49 Suppl 1:S13-8.

14. Lovegrove JA, Morgan JB, Hampton SM. Dietary factors influencing levels of food antibodies and antigens in breast milk. Acta Paediatr. 1996;85:778-84.

15. Vitolo MR, Bortolini GA, Feldens CA, Drachler Mde L. Impactos da implementação dos dez passos da alimentação saudável para crianças: ensaio de campo randomizado. Cad Saude Publica. 2005;21:1448-57.

16. Guilbert TW, Morgan WJ, Zeiger RS, Bacharier LB, Boehmer SJ, Krawiec $M$, et al. Atopic characteristics of children with recurrent wheezing at high risk for the development of childhood asthma. J Allergy Clin Immunol. 2004;114:1282-7.

17. Stein RT, Martinez FD. Asthma phenotypes in childhood: lessons from an epidemiological approach. Paediatr Respir Rev. 2004;5:155-61.

18. Holt PG. Parasites, atopy, and the hygiene hypothesis: resolution or a paradox? Lancet. 2000;356:1699-701.

19. van den Biggelaar $A H$, van Ree R, Rodrigues LC, Lell B, Deelder AM, Kremsner PG, et al. Decreased atopy in children infected with Schistosoma haematobium: a role for parasite-induced interleukin-10. Lancet. 2000;356:1723-7.

20. Horta BL, Olinto MT, Victora CG, Barros FC, Guimarães PR. Amamentação e padrões alimentares em crianças de duas coortes de base populacional no Sul do Brasil: tendência e diferenciais. Cad Saude Publica. 1996;12 Suppl 1:43-8.

21. Nejar FF, Segall-Corrêa AM, Rea MF, Vianna RP, Panigassi G. Padrão de aleitamento materno e adequação energética. Cad Saude Publica. 2004;20:64-71.

22. Carvalho Junior FF. Apresentação clínica da alergia ao leite de vaca com sintomatologia respiratória. J Pneumologia. 2001;27:17-24.

23. Sampson HA. Food allergy. Part 1: Immunopathogenesis and clinical disorders. J Allergy Clin Immunol. 1999;103:717-28.

24. Sampson HA. Food allergy. Part 2: Diagnosis and management. J Allergy Clin Immunol. 1999;103:981-9.

25. Leyer GJ, Li S, Mubasher ME, Reifer C, Ouwehand AC. Probiotic effects on cold and influenza-like symptom incidence and duration in children. Pediatrics. 2009;124:e172-9.

26. Mulder IE, Schmidt B, Stokes CR, Lewis M, Bailey M, Aminov $\mathrm{RI}$, et al. Environmentally-acquired bacteria influence microbial diversity and natural innate immune responses at gut surfaces. BMC Biol. 2009; 7:79.
27. Weinmayr G, Weiland SK, Björkstén B, Brunekreef B, Büchele $\mathrm{G}$, Cookson WO, et al. Atopic sensitization and the international variation of asthma symptom prevalence in children. Am J Respir Crit Care Med. 2007;176:565-74.

28. Pitrez PM, Stein RT. Asthma in Latin America: the dawn of a new epidemic. Curr Opin Allergy Clin Immunol. 2008;8:378-83.

29. Pereira MU, Sly PD, Pitrez PM, Jones MH, Escouto D, Dias AC, et al. Nonatopic asthma is associated with helminth infections and bronchiolitis in poor children. Eur Respir J. 2007;29:1154-60.

30. Stein RT. Long-term airway morbidity following viral LRTI in early infancy: recurrent wheezing or asthma? Paediatr Respir Rev. 2009;10 Suppl 1:29-31.

31. O'Donnell A, Torun B, Caballero B, Pantin EL, Bengoa JM. La alimentación del niño menores de 6 años en América Latina. Base para el desarrollo de Guias de Alimentación. Venezuela: Ediciones Cavendes; 1994.

32. Chulada PC, Arbes SJ Jr, Dunson D, Zeldin DC. Breast-feeding and the prevalence of asthma and wheeze in children: analyses from the Third National Health and Nutrition Examination Survey, 1988-1994. J Allergy Clin Immunol. 2003;111:328-36.

33. van Odjik J, Kull I, Borres MP, Brandtzaeg P, Edberg U, Hanson LA, et al. Breastfeeding and allergic disease: a multidisciplinary review of the literature (1966-2001) on the mode of early feeding in infancy and its impact on later atopic manifestations. Allergy. 2003;58:833-43.

34. Friedman NJ, Zeiger RS. The role of breast-feeding in the development of allergies and asthma. J Allergy Clin Immunol. 2005; 115:1238-48.

35. Tai A, Volkmer R, Burton AJ. Prevalence of asthma symptoms and atopic disorders in preschool children and the trend over a decade. Asthma. 2009;46:343-6.

36. Peroni DG, Piacentini GL, Bodini A, Boner AL. Preschool asthma in Italy: prevalence, risk factors and health resource utilization. Respir Med. 2009;103:104-8.

37. Vitolo MR, Bortolini GA, Campagnolo PD, Feldens CA. Effectiveness of a nutrition program in reducing symptoms of respiratory morbidity in children: a randomized field trial. Prev Med. 2008;47:384-8.

\author{
Correspondence: \\ Renato T. Stein \\ Instituto de Pesquisas Biomédicas da PUCRS \\ Departamento de Pediatria, FAMED \\ Av. Ipiranga, 6690, cj 420 \\ CEP 90610-000 - Porto Alegre, RS - Brazil \\ E-mail: rstein@pucrs.br
}

